\title{
A Study of the Role of Foreign Culture in Chinese International High School Students' English
}

\author{
Lei $\mathrm{Du}^{1, *}$ \\ ${ }^{l}$ Yichang Yilin Tianwen International High School, Yichang City, Hubei Province, China \\ ${ }^{*}$ Corresponding author. Email: yld11001@126.com
}

\begin{abstract}
International high schools are developing rapidly in China within these years. All the high school students will go abroad to study in the future, and they need to learn IELTS or TOEFL or SAT English or ACT English or other international English learning materials. Thus, language learning, requirement, and testing for them are different from those of ordinary schools. Under these conditions, culture learning is a factor worth considering in international high school students' language learning. This paper has found that students are interested in culture learning; they are most interested in economy, then legends/myths, weather, famous people's lifestyle, interesting things, and famous sayings, sports, geography, history, architecture, traditions, politics, and literature; their most preferred teaching methods for culture are movies, videos and role-plays. They all think culture can improve their class attention or performance as well as their language score. Based on the findings, this paper suggests that international high school teachers need to improve culture teaching using the methods mentioned above.
\end{abstract}

Keywords: international high school, language learning, culture, teaching methods, language teaching.

\section{INTRODUCTION}

International school in these years is developing fast in China. By the end of 2020, there are 907 international schools in China. International school expands from kindergarten, primary school, middle school to high school. All the international high school students are going abroad to further their university studies. Despite in the face of the novel coronavirus pandemic, the number of students intending to go abroad is still large, as parents with high degrees and prominent social status, especially those with affluence, are investing more in international education. And thus, students in international high schools are different from those from ordinary families. Most of the students have poor academic performance, bad study habits, and poor ability to acquire and apply a foreign language. However, language learning and test (like IELTS or TOEFL) is an important part of the international school, which is the precondition for applying for a renowned university and is the foundation for learning other subjects. For instance, to apply for a top 10 university in the United States, students should get a TOEFL score of at least 100, or an IELTS score of at least 7; to apply for a top 10 university in Britain, students should get an IELTS score of at least 6.5. Language is essential for international students, and international students spend much of their time on language learning. However, the result is not so satisfying. According to data released by British Council in 2020, the overall average IELTS score of Chinese mainland students is 5.72, which is far below the necessary score to apply for a prestigious university abroad. Based on these realities and requirements, international high schools' language course setting and goals are different from that of ordinary high schools.

Grade One students in international high school need to take some foundation courses of IELTS, like Secondary School IELTS Course. Grade Two and Grade Three students need to take IELTS courses, reading, listening, writing, and speaking, which occupy most of their English classes. The other courses are ACT or SAT English, GAC Reading and Writing, or other foreign textbooks. These courses are mainly set up to help students to get a high score on relevant tests, so teachers mostly focus on testing points, rarely teaching cultural elements. There are limited classes for teachers, and it needs much time for teachers to prepare content about culture. Therefore, class is becoming very monotonous. Students' needs of a real foreign language class with a complete teaching structure, language practice, language output, and expanded knowledge, like the cultural 
elements behind the learning material, are ignored. Students are trapped in this vicious circle.

However, culture plays an important role in foreign language learning. The definition of which given by UNESCO at the Second World Conference on Cultural Policies in Mexico in 1982 is: culture ought to be considered today the collection of distinctive traits, spiritual and material, intellectual and affective, which characterize a society or social group. Besides arts and letters, it comprises modes of life, human rights, value systems, traditions, and beliefs [1]. Therefore, the range of culture is very broad. The content of the learning materials is wide and closely related to the world, covering education, archaeology, history, technology, agriculture, industry, science, nature, animals, lifestyle, etc. However, both teachers and students do not attach great importance to cultural elements in the learning materials. Teachers merely want to help the students master some question-solving skills to get a high score. Similarly, students only focus on words, sentences, grammar, or testing points.

Even though Stagich claims culture context is the foundation and framework for understanding and developing competence in a foreign language. It is also the key to unlocking the door to understanding expressions, idioms, and inferences that would be difficult or even impossible to comprehend, and that is the reason why students spend years studying English grammar in school, they still have great difficulty in speaking, reading and writing English [2]. And From the beginning of the 20th century, there have been researches on cultural elements in the L2 curriculum [3] In the 1960s, second language learning was observed as "crosscultural communication and understanding" [4]. Adana points out that in the 1970 s, because of the development of Communicative Language Teaching, many researches were carried out to reveal the native and target cultures [5]. Then, In the late 1970s, with the improvement of Communicative Language Teaching's being a vital period for teaching culture, numerous researches were conducted in different countries to show the existence of different attitudes towards the use of native and target cultures. Since then, there are researches into the relationship between culture and language in the pedagogical aspect [5]. And Cunningsworth states that textbooks directly or indirectly convey cultural values, called 'hidden curriculum' [6]. Adana states that language and culture are intricately related to each other, and knowledge about culture can motivate learners to learn a language as learners can benefit from cultural knowledge [5]. While lack of knowledge about culture can lead to insufficient communication in the classroom, resulting in poor language performance.

However, research into the culture's role in language learning of international schools is rarely explored. In addition, students in an international school have special traits that are different from those in the studies mentioned above. So whether culture still promotes students' language learning is worth weighing and researching, and this paper explores culture's influence on international students' language learning.

\section{METHODOLOGY}

This study adopts the method of the questionnaire. There are 25 questions in this questionnaire, divided into 5 sections. The first section is about the subject's personal information; the second part is about the subject's attitude towards foreign culture; the third part is about the subject's attitude towards various teaching methods for foreign culture; the fourth part is about the subject's attitude towards culture content, and the last part is about the subject's evaluation about the teacher's culture teaching. Therefore, the subject's opinions towards culture learning and whether culture teaching influences their language learning can be obtained through this study.

In this study, the subjects are 21 students from Yicang Yiling Tianwen International High School, covering all the grades, from Grade One to Grade Three.

Table 1. Percentage of grade distribution

\begin{tabular}{lll}
\hline Grade & Number & Percentage \\
\hline 1 & 6 & 29 \\
2 & 14 & 67 \\
3 & 1 & 4 \\
\hline A total of 21 questionnaires were distributed in this
\end{tabular}
study, and 21 were returned. The recovery rate was $100 \%$. After careful inspection, the questionnaires returned were all valid. Thus the rate of the effective questionnaire was $100 \%$. After the questionnaires were collected, the answer to each question was counted, and then the in-depth question analysis was conducted.

\section{RESEARCH RESULT AND DISCUSSION}

This part is the data analysis of the subjects' questionnaires in Yichang Yiling Tianwen International High School to figure out the students' attitudes towards culture learning and whether culture teaching influences their language learning results.

The analysis is as the following.

In the second section, there are 7 questions about students' attitudes towards cultural learning. Students are asked to give a score from $0-5$, ' 0 ' is the lowest, ' 5 ' is the highest.

(1) Do you think foreign culture learning is important?

(2) Are you interested in learning about foreign culture? 
(3) Do you think certain knowledge of foreign culture promotes your communication with people from the target language?

(4) Do you think learning foreign culture can improve your interest in learning a foreign language?

(5) Do you think learning foreign culture can improve your inner motivation in learning a foreign language?

(6) Do you think learning foreign culture can improve your confidence in learning a foreign language?

(7) Do you think total immersion in a foreign culture can improve your language learning?

The result of these questions is shown in Table 2.

Table 2. Student number (N.) and occupancy rate(\%) of each score of every question (Q) in section two

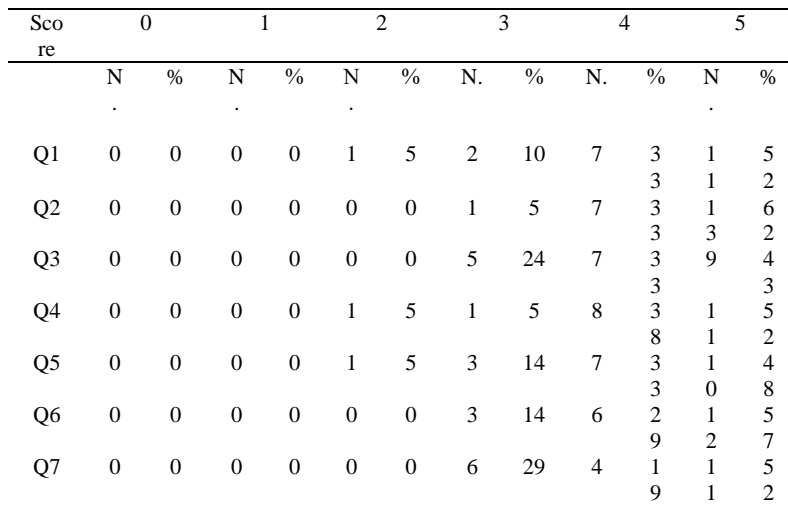

From the table, it can be seen that no students choose a score of 0 or 1 , and only three students choose the score of 2 , so nearly all students hold a positive attitude towards foreign culture. To be in detail, $85 \%$ of students think culture learning is important ( this is the totaling of scores 4 and 5), 95\% of students are interested in learning culture; $90 \%$ of students think culture learning can improve their interest in learning the language. As for the relationship between foreign culture learning and language learning, most students think foreign culture learning can help with foreign language learning from different dimensions, including communication with people from the target language $(76 \%)$, inner motivation (81\%), and confidence (86\%) in learning a foreign language, as well as language score $(76 \%)$. And $71 \%$ of students think total immersion in a foreign culture can improve their language learning.

The above data has shown that students have widely accepted the importance of foreign culture, and students' inner motivation and confidence can be boosted through learning foreign culture. This implies that foreign culture elements in foreign learning materials should be inserted in language classes. Teachers should not only focus on testing points. This can make the class boring and students' learning productivity very low. Besides, psychology claims that motivation is the impetus and power to encourage one person into certain action [6]. As students' inner motivation has been built, a long-term language willing will be set up within themselves. They will be eager to learn, brave to face English problems, and sort out solutions to solve them, thus promoting their language learning and score. Confidence can make them more attentive and active in class, which also plays an important role in language learning. Furthermore, the American Modern Linguist Krashen has once proposed that students will not be totally absorbed in knowledge from the teaching material. Students' learning motivation, attitudes, confidence, and anxiety can help students select the learning materials. Students who are confident in class will relatively fully absorb the knowledge in class and arrange it to add it into their own knowledge storage. While the students with weak confidence cannot fully take in all the knowledge taught in class. They will selectively learn or even reject the class [8].

In the third section, there are 6 questions about students' attitudes towards various teaching methods for foreign language. Students are asked to give a score from $0-5$, ' 0 ' is the lowest, ' 5 ' is the highest.

(1) Do you like English song competitions?

(2) Do you like watching English movies?

(3) Do you like role play for English language learning?

(4) Do you like seeing pictures or PPT introducing foreign culture?

(5) Do you like watching videos introducing foreign culture in class?

(6) Do you like being immersed in a totally foreign culture environment, like going to a foreign university or living in a foreign homestay?

The result of these questions is shown in Table 3.

Table 3. Student number (N.) and occupancy rate(\%) of each score of every question $(\mathrm{Q})$ in section three

\begin{tabular}{|c|c|c|c|c|c|c|c|c|c|c|c|c|}
\hline Scor & \multicolumn{2}{|c|}{0} & \multicolumn{2}{|c|}{1} & \multicolumn{2}{|c|}{2} & \multicolumn{2}{|c|}{3} & \multicolumn{2}{|c|}{4} & \multicolumn{2}{|c|}{5} \\
\hline & $\mathrm{N}$. & $\%$ & N. & $\%$ & N. & $\%$ & $\mathrm{~N}$. & $\%$ & N. & $\%$ & N. & $\%$ \\
\hline Q1 & 1 & 5 & 0 & 0 & 1 & 5 & 4 & $\begin{array}{l}1 \\
9\end{array}$ & 7 & $\begin{array}{l}3 \\
3\end{array}$ & 8 & 38 \\
\hline Q2 & 0 & 0 & 0 & 0 & 0 & 0 & 2 & $\begin{array}{l}1 \\
0\end{array}$ & 9 & $\begin{array}{l}4 \\
3\end{array}$ & 10 & 47 \\
\hline Q3 & 1 & 5 & 0 & 0 & 0 & 0 & 2 & $\begin{array}{l}1 \\
0\end{array}$ & 11 & $\begin{array}{l}5 \\
2\end{array}$ & 7 & 33 \\
\hline Q4 & 0 & 0 & 0 & 0 & 0 & 0 & 5 & $\begin{array}{l}2 \\
4\end{array}$ & 7 & $\begin{array}{l}3 \\
3\end{array}$ & 9 & 43 \\
\hline Q5 & 0 & 0 & 0 & 0 & 0 & 0 & 2 & $\begin{array}{l}1 \\
0\end{array}$ & 3 & $\begin{array}{l}1 \\
4\end{array}$ & 16 & 76 \\
\hline Q6 & 1 & 5 & 0 & 0 & 0 & 0 & 3 & $\begin{array}{l}1 \\
4\end{array}$ & 9 & $\begin{array}{l}4 \\
3\end{array}$ & 8 & 38 \\
\hline
\end{tabular}

It can be seen from the table that only 4 students choose a score less than 3 for all the questions. From score 3 to 5, the occupation rate is $90 \%$ or up $90 \%$ for each question. It can be thus referred that nearly all the teaching methods for foreign culture are accepted by the students, including English song competition, English movies, role play, pictures or PPT, videos, and 
immersion in a totally foreign culture. Among them, English movies, role play, and videos are especially welcomed by the students. The rates of the three are all up $85 \%$. Therefore, teachers can vary their teaching methods in the class, rather than just use one teaching method to make it more student-centered and interesting.

Teaching methods are very important, as the amount of knowledge students obtain from class is linked with teaching techniques [9]. The teaching method is a sort of teaching tool, which can give the students more clues about language and strengthen the interaction between students and teachers, as well as students and students. According to research, interaction learning is very effective for language learning, which can cultivate students' interest and confidence in language learning, help them form good study habits, develop their selfstudy ability and finally improve their comprehensive capability of using language. Therefore, the abovementioned teaching methods are recommended to the teachers.

In the fourth section, students are asked to give a score (0-5) to each culture content.

The culture contents are as the following:

\section{History}

Politics

Architecture

Literature

Movies

Traditions

Legends/Myths

Economy

Sports

Geography

Weather

Famous people's lifestyle, interesting things, famous sayings, etc.

After collecting the data, it is found that among them, economy ranks the first place, with a total score of 78 (adding up all the scores given by students to it), then the legends/myths (77), weather (72), famous people's lifestyle, interesting things and famous sayings (72), sports (71), geography (67), history (63), architecture (63), traditions (63), politics (62), and literature (61). So students are most interested in the economy. The students also welcome legends/myths, weather, famous people's lifestyle, interesting things, and famous sayings. The least welcomed are architecture, traditions, politics, and literature. This data suggests that to maximize students learning interests, teachers need to appropriately choose cultural content. Welcomed culture content such as content about the economy, legends/myths, weather, famous people's lifestyle, interesting things and famous sayings, sports, geography, and history should be given higher percentage, and the least welcomed culture content about politics and literature should be minimized. The reason is that when the students are interested in the cultural content, they will be more willing to focus their attention in class and devote their efforts to learning, and thus good learning results are brought. If students are not interested in the cultural content, the class will be regarded as very monotonous, and the interaction between students and teachers will be reduced. Thus the learning result will also be affected.

There are 5 questions about students' evaluation towards their language teacher's culture teaching in the last section. Students are asked to choose from: A. A lot B. A little C. Moderately $\quad$ D. Not at all

1. Does your teacher teach foreign culture?

2. How many percentages do foreign culture occupy your language teacher's one class?

3. Do you think culture teaching can improve your attention or performance in a class?

4. Do you think culture teaching can improve your language score?

5. Do you think foreign learning culture will make you more willing to study in that country?

The results are shown in Table 4.

Table 4. Student number (N.) and occupancy rate(\%) of questions $1,3,4$, and $5(\mathrm{Q})$ in section five

\begin{tabular}{ccccccccc}
\hline Choice & \multicolumn{2}{c}{ A lot } & A little & \multicolumn{2}{c}{$\begin{array}{c}\text { Moderatel } \\
\text { y }\end{array}$} & & Not at all \\
& & & & & N. & & \\
\hline & & &. & & & & N. & $\%$ \\
Q1 & 10 & 48 & 3 & 14 & 6 & 29 & 2 & 9 \\
Q3 & 7 & 33 & 6 & 29 & 8 & 38 & 0 & 0 \\
Q4 & 7 & 33 & 8 & 38 & 6 & 29 & 0 & 0 \\
Q5 & 12 & 57 & 6 & 29 & 3 & 14 & 0 & 0
\end{tabular}

For question 2: how many percentages do foreign culture occupy your language teacher's one class? 3 students choose "less than $10 \%$ ", 8 students choose $10 \%$ $30 \%, 9$ students choose to choose "more than $30 \%$," and 1 student choose " $0 \%$ ".

From the data, it can be seen that nearly all teachers teach foreign culture. However, the culture content is not enough. All students think culture can improve their attention or performance in class. All students think culture teaching can improve their language scores. All students think learning foreign culture will make them more willing to go to that country to study. Therefore, teachers should take the initiative to explore any opportunity to teach more cultural content in class to 
make culture teaching occupy a larger proportion. Teachers should attach great importance to culture when making teaching plan, to make the class student-centered with enough cultural content. This can facilitate students' learning autonomy, motivation and productivity. Because students-centered classes change the students from passive learners to active learners, and change the teachers from knowledge irrigators to instructors, promotors and consultants [10].

\section{CONCLUSION}

Currently, studying in an international high school is a trend. Students in international high school are embracing new opportunities, as they will go abroad to further their universities. This enables them to meet new foreign cultures, adapt to different learning systems, encounter new people, etc. Meanwhile, they are also facing some language learning difficulties. The language requirements, testing points, and contents are different from those in ordinary high school. Based on the special condition and testing contents, inserting culture into teachers' teaching is important.

The reason is that the above data has shown that students have widely accepted the importance of foreign culture, and students' inner motivation and confidence can be boosted through learning foreign culture; all the students think culture teaching is important and can improve their language score, as well as their attention and performance in class. However, the current culture teaching is not enough. There are many cultural elements in all the foreign learning materials, including American history, gap-year work, traveling in different countries, foreign people's lifestyle, civilizations, and economy in different countries. Teachers should be acute in the cultural elements in teaching materials to outline them and use different teaching methods, like the most welcomed ones: movies, videos or role-plays, and less welcomed ones: English song competition, pictures or PPT to teach culture and make creative teaching with culture as its feature. Thus, the language class can be rich, vivid, meaningful, interesting, highly efficient, and thought-cultivating with cultural characteristics rather than monotonous and boring.

\section{REFERENCES}

[1] D. Paul Schafer, The character of culture, World Culture Project, Scarborough, 1989.

[2] T. Stagich, Cultural context: the key to second language learning and acquisition, Educational Horizons, 73(2), 1995, pp. 59-61.

[3] M. Byram, Assessing intercultural competence, Sprogforum, No. 18, Vol. 6, 2000, pp. 8-13.
[4] M. Lessard-Clouston, Towards an understanding of culture in L2/FL education, The Internet TESL Journal, No. 5, Vol. III, 1997.

[5] Adana, An investigation on the cultural elements in a Turkish textbook for foreigners, Social and Behavioral Sciences 158, 2014, pp. 356 - 363.

[6] A. Cunningsworth, Choosing your coursebook, Heinemann, Oxford, 1995.

[7] Y. Xu, A study of the effects of inner motivation on English study result, English on Campus, 2015.

[8] R. F. Yang, F. Xu, A study of the importance of confidence in university English study, Language and Culture Study.

[9] J. J. Beck, Perceived relative importance of content and process to effective teaching.

[10] Q. C. Yu, J. X. He, Students-centered classconstructing a new model of university English teaching, No. 117, 2006. 